\title{
Microsatellite analysis of genetic diversity and structure of Bruguiera gymnorrhiza and Kandelia obovate
}

\author{
Mohammad Basyuni ${ }^{1,2 *}$, Shigeyuki $\mathrm{Baba}^{3}$, and Hirosuke $\mathrm{Oku}^{4}$ \\ ${ }^{1}$ Department of Forestry, Faculty of Forestry, Universitas Sumatera Utara, Jl. Tri Dharma Ujung No. \\ 1 Medan, North Sumatera 20155, Indonesia \\ ${ }^{2}$ Mangrove and Bio-Resources Group, Center of Excellence for Natural Resources Based \\ Technology, Universitas Sumatera Utara, Medan North Sumatera 20155, Indonesia \\ ${ }^{3}$ International Society for Mangrove Ecosystems, Faculty of Agriculture, University of the Ryukyus, \\ 1 Senbaru, Nishihara, Okinawa 903-0213, Japan \\ ${ }^{4}$ Molecular Biotechnology Group, Tropical Biosphere Research Center, University of the Ryukyus, 1 \\ Senbaru, Nishihara, Okinawa 903-0213, Japan
}

\begin{abstract}
Microsatellite loci were used for estimating genetic diversity and structure for three populations of B. gymnorrhiza and $K$. obovata (Rhizophoracea) in Okinawa, Japan. Thirty propagules of individual samples representing the population of both species were genotyped at five microsatellites. The level of observed heterozygosity $\left(H_{\mathrm{O}}\right)$ was observed for several population, overall loci, ranged $0.422-0.800$ with an average 0.627 for B. gymnorrhiza and 0.477-0.822 with an average 0.665 for $K$. obovata, indicating both species had relatively low genetic diversity. Both species showed low levels of allelic diversity, 3-5 and 3-5 alleles per locus, respectively. Gene diversitywas also maintained within populations $\left(H_{\mathrm{s}}\right.$ : 0.741 and 0.954). Additionally, an analysis of molecular variance (AMOVA) based on the immeasurable alleles model ( $F$-statistics), for $B$. gymnorrhiza and $K$. obovata found that most of the variation resided within individuals in the total populations, i.e. $79.78 \%$ and $69.90 \%$ respectively, and among individuals within populations, i.e.14.30\% and $27.95 \%$ respectively. There was little variation between populations, i.e. $5.92 \%$ and $2.15 \%$ for B. gymnorrhiza and K. obovata, respectively. The high-level genetic differentiation within individuals and populations both species may be due to the geographic range of the species, mating system, and environmental factors.
\end{abstract}

\section{Introduction}

Mangroves are typically tropical and sub-tropical coastal vegetation. In Japan, natural mangrove forests mainly distribute around Ryukyu Islands group, growing well in Okinawa,

*Correspondent Author: m.basyuni@usu.ac.id 
Iriomote Island, Ishigaki Island, and Amami Island in its northern Japanese limit on southern Kyushu [1]. The mangrove area at Okukubi River and Katabaru River, Okinawa are inhabited by four significant species, including Bruguiera gymnorrhiza, Kandelia obovata, Rhizophora stylosa, and Lumnitera racemosa. B. gymnorrhiza is denser in population, growing taller, and preferring to grow under covered conditions, while $K$. obovata and $R$. stylosa need more sunlight [2].

One of the important characterizations of mangroves Rhizophoracea is the production of viviparous offspring. Their propagules develop into seedling while they are still attached to the mother tree. In viviparous mangrove species, the embryo ruptures the pericarp, grows beyond it before dispersals such as B. gymnorrhiza, K. obovata and many other species of Rhizophoracea [3-4]. However, the effect of this important dispersal mechanism on the level genetic variation within and among populations is not much concerned.

In addition, the rate of gene flow through seed dispersal of a species also plays an essential role in determining population genetic structure. The restricted mangroves area in Japan, therefore the conservation and management resources have become an urgent task. Reliable information on the distribution of population genetic structure and mating system of mangrove tree species is essential to establish an active network of conservation populations [5].

Therefore, the present study was aimed to investigate population genetic diversity and structure of two mangrove species, B. gymnorrhiza and $K$. obovata. Information of genetic variation parameters will not only clarify the pattern of population genetic structure but also contribute to its protection, management, and utlization of mangrove tree genetic resources.

\section{Materials and methods}

\subsection{Study site and sample collection}

This study site was carried out in Okukubi River and Katabaru River, Okinawa, Japan. Thirty propagules per tree as materials for progeny arrays was used. While 30 propagules each species representing as population (Okukubi left side, Okukubi right side, and Katabaru) as shown in Fig. 1. Collected samples were kept at $-80^{\circ} \mathrm{C}$ until required for DNA extraction. 


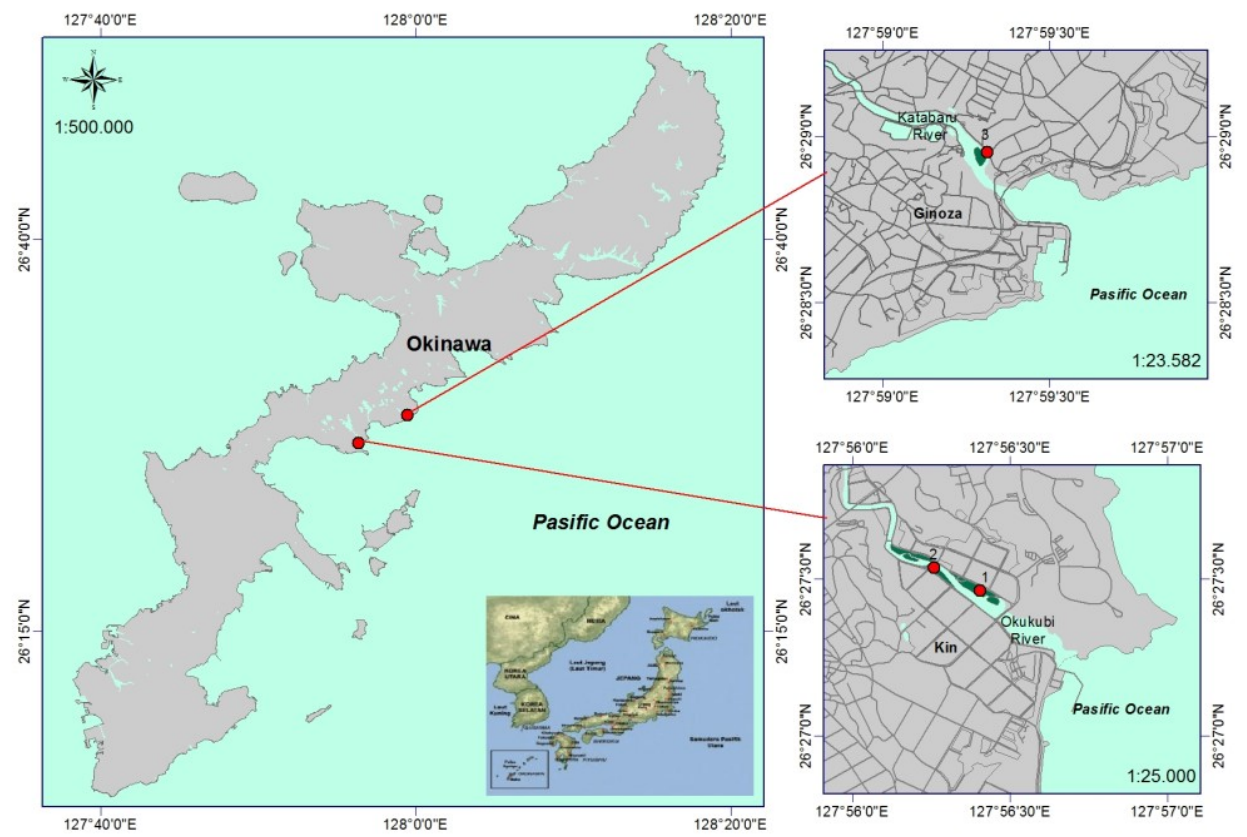

Fig. 1. Study site of Okukubi River and Katabaru River, Okinawa, Japan

\subsection{DNA extraction and microsatellite analysis}

Total DNA was extracted from the propagules as progeny arrays using modified CTAB procedure [6]. Five primer pairs, MSBgy025, MSBgy027, MSBgy030, MSBgy031 and MSBgy188 [7] were used in B. gymnorrhiza as well as five primer pairs (Kcan004, Kcan005, Kcan009, Kcan011, and Kcan034) of K. obovata according to Sugaya et al. [8]. PCR mixtures condition $(10 \mu \mathrm{l})$ contained $10 \mathrm{X}$ Ex Taq, $1.5 \mathrm{mM} \mathrm{MgCl} 2,0.2 \mathrm{mM}$ of each dNTP, $0.1 \mu \mathrm{M}$ of each primer (fluorescent forward and reverse), $10 \mathrm{ng}$ genomic DNA and $1.0 \mathrm{U}$ of Taq polymerase. PCR amplification was performed for $3 \mathrm{~min}$ at $94^{\circ} \mathrm{C}$ for, continued by 35 cycles of $1 \mathrm{~min}$ at $94^{\circ} \mathrm{C}, 30 \mathrm{~s}$ at the improved annealing temperature and 30 s $72^{\circ} \mathrm{C}$, with a final extension of $5 \mathrm{~min}$ at $72^{\circ} \mathrm{C}$ using a PCR System Model PC-806 (ASTEC). The amplicons were detached using an ABI PRISMR 310 Genetic Analyzer and genotypes were analyzed by GeneScanTM and ABI PRISMTM Genotyper software version 2.0. (PE Applied Biosystems).

\subsection{Data Analysis}

\subsubsection{Genetic diversity}

Genetic diversity overall populations and all microsatellite loci were estimated as the mean number of alleles per locus $(A)$, mean expected heterozygosity $\left(H_{\mathrm{E}}\right)$, mean observed heterozygosity $\left(H_{\mathrm{O}}\right)$ and the inbreeding coefficient $\left(F_{\mathrm{IS}}\right)$ using GDA, version 1.1 [9]. Genetic differentiation between populations was calculated according to Nei's gene diversity within a population (HS), gene diversity between populations $\left(D_{\mathrm{ST}}\right)$, the 
coefficient of gene diversity $\left(G_{\mathrm{ST}}\right)$ [10], and calculating of allelic richness $\left(A_{\mathrm{R}}\right)$ implemented by FSTAT version 2.9.3 [11].

F-statistics $\left(F_{\mathrm{IS}}, F_{\mathrm{IT}}\right.$, and $\left.F_{\mathrm{ST}}\right)$ were computed every locus. The possibility of the $F$ statistics being more significant than zero was detected by bootstrap analysis using 1000 repeated, with a 99\% confidence distance, using GDA, version 1.1 [9].

\subsubsection{Genetic structure}

Determination of genetic structure was done using the unbounded alleles model [12]. Analysis of molecular variance (AMOVA) [13] to quantity variance components and their importance between populations, among individuals within populations, and within populations were computed using the ARLEQUIN version 2.000 [14], in which significance levels for the overall values were decided after 1023 permutations.

To estimate gene flow, multilocus calculates the mean effective number of migrants $(\mathrm{Nm})$ between population using private allele methods of Slatkin (1985) and were adjusted for sample size as provided in Barton \& Slatkin [15], implemented by program GENEPOP version $3.1 b$ [16].

\section{Results and discussion}

\subsection{Genetic diversity}

The microsatellite loci of $B$. gymnorrhiza and $K$. obovata were lowly polymorphic with 3-5 and 3-5 alleles per locus, with five microsatellite loci respectively (Table 1). In $B$. gymnorrhiza, allele sizes ranged from 200 to 257 reappearances for locus MSBgy025, from 50 to 79 repeats for MSBgy027, from 50 to 70 for locus MSBgy030, from 160 to 200 reiterations for locus MSBgy031, and from 139 to 167 replications for locus MSBgy188. At the species level, the mean observed heterozygosity $\left(H_{\mathrm{O}}\right)$, mean expected heterozygosity $\left(H_{\mathrm{E}}\right)$, mean gene diversity within the population $\left(H_{\mathrm{S}}\right)$, and mean coefficient of gene differentiation $\left(G_{\mathrm{ST}}\right)$ were $0.627,0.744,0.741$, and 0.045 respectively (Table 1$)$. At the population, the mean observed heterozygosity $\left(H_{\mathrm{O}}\right)$, mean expected heterozygosity $\left(H_{\mathrm{E}}\right)$ and mean inbreeding coefficient $\left(F_{\text {IS }}\right)$ was $0.627,0.926$, and 0.144 respectively (Table 2 ).

In K. obovata allele sizes diverged from 390 to 480 repeats for locus Kcan004, from 350 to 400 recurrences for Kcan005, from 285 to 350 repeats for locus Kcan009, from 200 to 246 replications for locus Kcan011, and from 75 to 170 duplications for locus Kcan034. At the species level, the mean observed heterozygosity $\left(H_{\mathrm{O}}\right)$, mean expected heterozygosity $\left(H_{\mathrm{E}}\right)$, mean gene diversity within the population $\left(H_{\mathrm{S}}\right)$, and mean coefficient of gene differentiation $\left(G_{\mathrm{ST}}\right)$ were $0.665,0.966,0.954$ and 0.014 respectively (Table 1$)$. At the population, the average observed heterozygosity $\left(H_{\mathrm{O}}\right)$, average expected heterozygosity $\left(H_{\mathrm{E}}\right)$, and mean inbreeding coefficient $(F \mathrm{IS})$ was $0.665,0.966$, and 0.298 , correspondingly.

Table 1. Profile of microsatellite loci overall populations in (a) offspring B. gymnorrhiza and (b)

\begin{tabular}{|l|c|c|c|c|c|c|c|}
\hline Locus & $\mathbf{A}$ & $\boldsymbol{A}_{\mathbf{R}}$ & $\boldsymbol{H}_{\mathbf{E}}$ & $\boldsymbol{H}_{\mathbf{O}}$ & $\boldsymbol{H}_{\mathbf{S}}$ & $\boldsymbol{D}_{\text {ST }}$ & $\boldsymbol{G}_{\mathbf{S T}}$ \\
\hline (a) B. gymnorrhiza & & & & & & & \\
MSBgy025 & 3 & 2.89 & 0.707 & 0.678 & 0.710 & 0.045 & 0.064 \\
MSBgy027 & 5 & 3.56 & 0.790 & $0.433^{* *}$ & 0.759 & 0.033 & 0.041 \\
MSBgy030 & 4 & 3.07 & 0.829 & $0.422^{* *}$ & 0.795 & 0.036 & 0.043 \\
MSBgy031 & 4 & 3.50 & 0.791 & 0.800 & 0.740 & 0.053 & 0.067 \\
MSBgy188 & 4 & 3.66 & 0.755 & 0.800 & 0.748 & 0.008 & 0.010 \\
Mean & 4 & 3.34 & 0.744 & 0.627 & 0.741 & 0.035 & 0.045 \\
\hline
\end{tabular}




\begin{tabular}{|l|c|c|c|c|c|c|c|}
\hline Locus & $\mathbf{A}$ & $\boldsymbol{A}_{\mathbf{R}}$ & $\boldsymbol{H}_{\mathbf{E}}$ & $\boldsymbol{H}_{\mathbf{O}}$ & $\boldsymbol{H}_{\mathbf{S}}$ & $\boldsymbol{D}_{\mathbf{S T}}$ & $\boldsymbol{G}_{\mathbf{S T}}$ \\
\hline (b) K. obovata & & & & & & & \\
Kcan004 & 3 & 2.11 & 0.985 & 0.759 & 0.980 & 0.005 & 0.005 \\
Kcan005 & 4 & 2.91 & 0.943 & $0.545^{* *}$ & 0.933 & 0.013 & 0.014 \\
Kcan009 & 5 & 3.27 & 0.976 & 0.822 & 0.953 & 0.023 & 0.023 \\
Kcan011 & 4 & 3.90 & 0.971 & 0.722 & 0.969 & 0.005 & 0.005 \\
Kcan034 & 5 & 3.47 & 0.952 & $0.477^{* *}$ & 0.932 & 0.022 & 0.023 \\
Mean & 4.2 & $3 . .3$ & 0.966 & 0.665 & 0.954 & 0.014 & 0.014 \\
\hline
\end{tabular}

$A$ : number of alleles detected, $A_{\mathrm{R}}$ : allelic richness, $H_{\mathrm{E}}$ : expected heterozygosity, $H_{\mathrm{O}}$ : observed heterozygosity, $H_{\mathrm{s}}$ : gene diversity within the population, $D \mathrm{ST}$ : gene diversity between populations, $G$ sт: coefficient of gene differentiation. The deviation from Hardy-Weinberg equilibrium was calculated using a $\chi$ test, $* * P<0.01$

Table 2. Descriptive statistics over all loci for three populations of B. gymnorrhiza and K. obovata

\begin{tabular}{|l|c|c|c|c|c|c|}
\hline Population & $\boldsymbol{N}$ & $\boldsymbol{A}$ & $\boldsymbol{H}_{\boldsymbol{E}}$ & $\boldsymbol{H}_{\mathbf{O}}$ & $\boldsymbol{F}_{\text {IS }}$ & Outcrossing rate \\
\hline (a) B. gymnorrhiza & & & & & & \\
Katabaru & 30 & 9.2 & 0.754 & 0.673 & 0.108 & 0.805 \\
Okukubi left & 30 & 5.8 & 0.671 & 0.680 & -0.014 & 1.028 \\
Okukubi right & 30 & 9.6 & 0.790 & 0.527 & $0.337^{*}$ & 0.495 \\
Mean & 30 & 8.2 & 0.738 & 0.627 & 0.144 & 0.776 \\
(b) K. obovata & & & & & & \\
Katabaru & 29.6 & 26.6 & 0.931 & 0.704 & 0.241 & 0.612 \\
Okukubi left & 29.4 & 24.8 & 0.955 & 0.618 & $0.351^{*}$ & 0.480 \\
Okukubi right & 29.6 & 30.6 & 0.958 & 0.673 & 0.302 & 0.536 \\
Mean & 29.5 & 27.3 & 0.948 & 0.665 & 0.298 & 0.543 \\
\hline
\end{tabular}

$N$ : sample size over all loci, $A$ : number of alleles detected, $H_{\mathrm{E}}$ : expected heterozygosity, $H_{\mathrm{O}}$ : observed heterozygosity, $F_{\text {IS }}$ : inbreeding coefficient, ${ }^{a}[31]$. The deviation from Hardy-Weinberg equilibrium was assessed using a $\chi$ test, $* P<0.1$

Both species of the three populations, one involved critical departures from HardyWeinberg equilibrium (HWE); Which correspond to that population with substantial levels of inbreeding $\left(F_{\mathrm{IS}}\right)$ (Table 3$)$. In each case, deviations from HWE were due to homozygote overabundance.

Table 3. Estimates of $F$-statistics for each locus and over all loci all populations. $F$ - statistics bootstrap analysis obtains bootstrap confidence intervals $F$-statistic, using 1000 replicates and $99 \%$ confidence interval $(\mathrm{CI})$

\begin{tabular}{|l|c|c|c|}
\hline Locus & $\boldsymbol{F}_{\text {IS }}$ & $\boldsymbol{F}_{\text {IT }}$ & $\boldsymbol{F}_{\text {ST }}$ \\
\hline (a) B. gymnorrhiza & & & 0.094 \\
\hline MSBgy025 & -0.026 & 0.071 & 0.061 \\
\hline MSBgy027 & 0.429 & 0.464 & 0.063 \\
\hline MSBgy030 & 0.469 & 0.502 & 0.099 \\
\hline MSBgy031 & -0.087 & 0.021 & 0.012 \\
\hline MSBgy188 & -0.069 & -0.056 & 0.066 \\
\hline Overall loci & 0.153 & 0.209 & \\
\hline Bootstrap CI & & & 0.097 \\
\hline Upper & 0.461 & 0.495 & 0.031 \\
\hline Lower & -0.076 & -0.031 & 0.008 \\
\hline (b) K. obovata & & & 0.021 \\
\hline Kcan004 & 0.226 & 0.288 & 0.035 \\
\hline Kcan005 & 0.415 & 0.427 & 0.007 \\
\hline Kcan009 & 0.138 & 0.168 & 0.034 \\
\hline Kcan011 & 0.232 & 0.238 & 0.506 \\
\hline Kcan034 & 0.488 & & \\
\hline
\end{tabular}




\begin{tabular}{|l|c|c|c|}
\hline Locus & $\boldsymbol{F}_{\text {IS }}$ & $\boldsymbol{F}_{\text {IT }}$ & $\boldsymbol{F}_{\text {ST }}$ \\
\hline Overall loci & 0.298 & 0.313 & 0.021 \\
\hline Bootstrap CI & & & \\
\hline Upper & 0.475 & 0.459 & 0.035 \\
\hline Lower & 0.193 & 0.174 & 0.008 \\
\hline
\end{tabular}

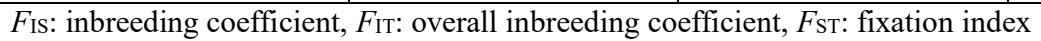

\subsection{Genetic structure}

To measure the degree of population distinction the infinite alleles model $\left(F_{\mathrm{ST}}\right)$ was used. The total value of genetic differentiation for this model resulted different values and significantly different from zero $(P<0.1): F_{\mathrm{ST}} B$. gymnorrhiza and $K$. obovata were 0.066 and 0.021 respectively, indicates significant structure population exist within populations. The overall values of $F_{\text {IS }}$ both were 0.153 and 0.298 respectively, suggesting little to no breeding. The overall values of $F_{\text {IT }}$ both were 0.209 and 0.313 respectively (Table 3), indicating a moderately high correlation between alleles within individuals relative to the allelic array of the total populations.

For $F_{\mathrm{ST}}$, the greater of all pairwise comparisons were significantly higher than zero $(P<$ 0.005). Using Wright's manual [17], for $F_{\mathrm{ST}}$ all populations pairs in $K$. obovata and one population pair in $B$. gymnorrhiza in the limit $0.00-0.05$ and two population pairs in $B$. gymnorrhiza in the range 0.05-0.15 (Table 3), suggesting moderate and little genetic diversity.

Table 4. Hierarchical analysis of molecular variance (AMOVA) of three populations of $B$. gymnorrhiza and K. obovata

\begin{tabular}{|c|c|c|c|c|c|}
\hline \multirow{2}{*}{ Source of variation } & \multirow[t]{2}{*}{ d.f. } & \multirow{2}{*}{$\begin{array}{l}\text { Sum of } \\
\text { squares }\end{array}$} & \multicolumn{2}{|c|}{ Variance component } & \multirow[b]{2}{*}{$\mathbf{P}$} \\
\hline & & & Absolute & $\%$ & \\
\hline \multicolumn{6}{|l|}{ B. gymnorrhiza } \\
\hline Among populations & 2 & 18.909 & 0.11774 & & $<0.001$ \\
\hline Among individuals & & & & 5.92 & \\
\hline Within populations & 90 & 193.903 & 0.28423 & & $<0.001$ \\
\hline Within individuals & 93 & 147.500 & 1.58602 & 14.30 & $<0.001$ \\
\hline Total & 185 & 360.312 & 1.98799 & 79.78 & \\
\hline K. obovata & & & & & \\
\hline Among populations & 2 & 12.033 & 0.05079 & & $<0.001$ \\
\hline Among individuals & & & & 2.15 & \\
\hline Within populations & 87 & 258.350 & 0.65977 & & $<0.001$ \\
\hline Within individuals & 90 & 148.500 & 1.65000 & 27.95 & $<0.001$ \\
\hline Total & 179 & 148.883 & 2.36056 & 69.90 & \\
\hline
\end{tabular}

d.f.: degrees of freedom, P: P-value

Both species of these populations also had to estimate of the number migrants $(\mathrm{Nm})>1$, indicates some gene flow. For B. gymnorrhiza predicts of the number of migrants between Katabaru and Okukubi right, Katabaru and Okukubi left, Okukubi right and Okukubi left were $2.659,1.788$, and 1.189 respectively. Whereas for $K$. obovata estimates of the number of migrants between Katabaru and Okukubi right, Katabaru and Okukubi left, Okukubi right and Okukubi left were 5.128, 3,486, and 3.999 respectively. Overall populations and loci, both species the number of migrants using the private alleles method based to Barton and Slatkin [15] were 1.826 and 4.681 respectively, indicating relatively high of private alleles in these populations with the mean frequency of private alleles $p(1)=0.049$ and 
0.029 respectively. It is noteworthy, however, that these values of $N \mathrm{~m}$ correspond to a historical average of the number of migrants per generation.

The genetic structure was also tested by analysis of molecular variance (AMOVA) using on the infinite alleles model (Table 4), both species showed that most variation was among individuals within population $(14.30 \%$ and $27.35 \%$ respectively) and within individuals in the total populations $(79.78 \%$ and $69.90 \%$ respectively), indicating significant genetic differentiation within individuals. There was littlevariation between populations (5.92\% and $2.15 \%$ respectively).

For $B$. gymnorrhiza, the levels of genetic variation, the mean of the number of alleles per locus $(A)$, and the average of gene diversity $\left(H_{\mathrm{E}}\right)$ were comparatively high with 3-5 and 0.744 respectively than those reported previously using allozymes marker [18] observed the genetic diversity values $\left(A=1.10\right.$ and $\left.H_{\mathrm{E}}=0.035 \pm 0.025\right)$. The levels of heterozygosity $\left(H_{\mathrm{O}}\right)$ detected for every population, overall loci (Table 3 ), indicate that these populations had relatively high genetic variation, these calculations of heterozygosity were much higher than those descrbed prior using allozyme to estimate $H_{\mathrm{O}}=0.009$ [18]. Similarly, Sugaya et al. [7] also reported the genetic variation values of $B$. gymnorrhiza $\left(A=2-5, H_{\mathrm{O}}=0.031\right.$ $0.500)$ using microsatellite marker.

Meanwhile, $K$. obovata also showed the high level of genetic diversity $(A=46-73$, $\left.H_{\mathrm{E}}=0.966\right)$. The observed heterozygosity $\left(H_{\mathrm{O}}=0.665\right)$ was much higher than those reported previously using allozyme marker [19] found the gene diversity $\left(H_{\mathrm{E}}\right)$ and the number of alleles per locus were 0.033 and $1.11 \pm 0.04$ respectively. Huang et al. [20] reported the values of genetic diversity $\left(A=1.2, H_{\mathrm{O}}=0.04, H_{\mathrm{E}}=0.049\right)$ in $B$. gymnorrhiza, Southern China. Meanwhile, Takeuchi et al. [18] demonstrated the low level of genetic variation in $K$. obovata, Southwest of Japan $\left(H_{\mathrm{E}}=0.012 \pm 0.012\right)$. However, using microsatellite marker, Sugaya et al. [8] reported high values $\left(A=3-9, H_{\mathrm{O}}=0.250-0.938\right)$ in $K$. obovata. Factors such as isolation, small populations and gene flow, all of which directly affect useful population sizes, may have a significant influence on the levels of genetic diversity observed within and among populations of woody species [21]. In addition, the hierarchical analysis of molecular variance (AMOVA) of both species also showed that most of the diversity was separated among individuals within populations and within individuals in the total populations. There was little variation among populations. Differences in the breeding system may result in dissilimarity in population genetic structure. Hamrick et al. [21] pointed out that in outcrossing species, the majority of the total genetic diversity $\left(H_{\mathrm{E}}\right)$ located within populations $\left(H_{\mathrm{S}}\right)$, whereas in selfing species is more distributed among populations $\left(F_{\mathrm{ST}}\right)$. In this study, the genetic diversity of both species maintained within populations with the relatively high of $H_{\mathrm{S}}, 0.741$ and 0.954 respectively (Table 4 ).

The comparable results were obtained for other mangroves tree species. Partitioning of variation was detected within the populations of $B$. gymnorrhiza $(70 \%)$, and for $B$. sexangula $60 \%$ of the difference was observed among populations [22]. Jian et al. [23] reported the variation within populations of Heritiera littoralis from Australia and China and within China were $46.9 \%$ and 72.2 respectively. Basyuni et al. [6] observed in Rhizophora mangle from Ecuador that the variation was partitioned among individuals within populations $(33.3 \%)$ and among individuals $(66.6 \%)$ in the total populations. Meanwhile, the genetic variation of Sonneratia alba in China was maintained within populations, 79.39 [24].

Also, assessment of genetic variation of population levels throughout the worldwide range of $A$. marina showed that most variation was found between populations $(41-71 \%)$ and within individuals in the total populations (31-49\%) [25]. Hamrick et al. [21] reported that studies on genetic diversity within populations of woody species showed that a high level of genetic diversity mostly resides within populations. 
The discrete subpopulation model indicated little and moderate levels of genetic differentiation using Wright's interpretive guidelines [17] (Table 6). The extent and the pattern of genetic diversity in forest trees are strongly regulated by their mating system and gene flow [26]. Indirect estimates of gene flow using private alleles resulted relatively high for overall population of both species $(\mathrm{Nm}=1.826$ and 4.681 , respectively). If $\mathrm{Nm}$ is less than 1, then changes in allele frequencies resulting from a genetic drift of neutral alleles can occur. Such changes are not likely if $N \mathrm{~m}$ is greater than 1 [27]. Moreover, viviparous seed dispersal is potentially a much greater source of gene flow in mangroves [20].

As measured by electrophoretically distinguishable alleles, which are often considered to be neutral variations, the value for $\mathrm{Nm}$ in a range of forest tree species indicates fairly high levels $(>1)$ of gene flow. This is to be expected because most trees have high outcrossing rates, and there is a definite association between outcrossing rate and the level of gene flow [28]. The high value of $\mathrm{Nm}$ for both species is comparable to estimates reported for other mangroves tree species, such as in $R$. mangle in Pacific coast, $N \mathrm{~m}=3.174$ [29] and $R$. mangle in Ecuador, $N m=3.778$ [6].

Gene flow switch of gametes or genes among distributed trees, and it is reciprocally correlated to population adjustment. It occurs through the forward motion of pollen and seed, which can be incoherent by a broad varied of non-living and living mechanisms. Understanding how populations are dispread, preserved, or restricted by gene flow is indispensable for control precise tree populations in their primary environment [30].

The structure of genetic diversity within and among populations of species is an inherent feature of the evolution of mangrove forest, that may be correlated to evolutionarily oxidosqualene gene and salt tolerance gene [31-32], and must, therefore, be considered in developing any conservation strategy. Our results suggested supporting the conservations efforts of the mangrove ecosystem in Okinawa. The protection implies of the available data of these studies on genetic variation and structure are that, in the conditon of outcrossing species, some populations in Okinawan mangroves, especially B. gymnorrhiza and $K$. obovata may sustain much of the genetic diversity.

\section{Acknowledgements}

A part of this study was funded by an International Research Collaboration 2016-2018 from the Directorate for Research and Community Service, Ministry of Research, Technology and Higher Education, Republic of Indonesia.

\section{References}

1. M. Basyuni, H. Sagami, S. Baba, H. Iwasaki, H. Oku, Diversity of polyisoprenoids in ten Okinawan mangroves, Dendrobiology 75, 167-175 (2017).

2. K. Kathiresan, S. Baba, Facts about mangroves of Japan. Seshaiyana 7:3-6 (1999).

3. M.Z. Hussain, Silviculture of Mangroves. Unasylva 181 (46):36-42 (1995).

4. M. Basyuni, H. Sagami, S. Baba, H. Oku, Distribution, occurrence, and cluster analysis of new polyprenyl acetones and other polyisoprenoids from North Sumatran mangroves, Dendrobiology 78, 18-31 (2018).

5. L. Graudal, E. Kjaer, A. Thomsen, and A.B. Larsen, Planning national programmes for conservation of forest genetic resources. Danida Forest Seed Centre. Technical Note 48: 9-25 (1997)

6. M. Basyuni, S. Baba, H. Oku, IOP Conference Series Materials Science and Engineering 180, 1, p. 012243 (2017). 
7. T. Sugaya, T. Takeuchi, H. Yoshimaru, and M. Katsuta, Development and polymorphism of simple sequence repeat DNA markers for Kandelia candel (L.) Druce. Molecular Ecology Notes 2:65-66, (2002).

8. T. Sugaya, H.Yoshimaru, T.Takeuchi, M.Katsuta, K.Fujimoto,and S.Changtragoon, Development and polymorphism of simple sequence repeat DNA markers for Bruguiera gymnorrhiza (L.) Lamk. Molecular Ecology Note 3:88-90, (2003).

9. P.O. Lewis, and D. Zaykin, Genetic Data Analysis: Computer program for the analysis of allelic data, version 1.1. Free program distributed over the internet from GDA homepage at http://hydrodictyon.eeb.uconn.edu/people/plewis/software.php (2002).

10. M. Nei, Molecular evolutionary genetics, (Columbia University Press, New York. 512pp, 1987).

11. J. Goudet, FSTAT, a program to estimate and test gene diversities and fixation indices (version 2.9.3). (2001)

12. M. Kimura, and J. Crow, The number of alleles that can be maintained in a finite population. Genetics 49:725-738, (1964)

13. S. Schneider, D. Roessli, and L. Excoffier, ARLEQUIN version 2.000: A software for populations genetics data analysis, (Genetics and Biometry Laboratory, University of Geneva, Switzerland, 2000)

14. M. Raymond, and F. Rousset, GENEPOP (Version 3.1b): Population genetics software for exact tests and ecumenicism. Journal of Heredity 86:248-249 (1995)

15. S. Wright, The interpretation of population structure by F-statistics with special regard to system of mating, Evolution 19:395-420 (1965).

16. T. Takeuchi, T. Sugaya, A. Kanazashi, H. Yoshimaru, and M. Katsuta, Genetic diversity of Kandelia candel and Bruguiera gymnorrhiza in the Southwest Islands, Japan. J.For.Res. 6:157-162, (2001).

17. M. Sun, K. C. Wong, and J. S. Y. Lee, Reproductive biology and population genetic structure of Kandelia candel (Rhizophoraceae), a viviparous mangrove species. American Journal of Botany 85(11):161-1637 (1998).

18. S. Huang, Y. Chen., and H. Fan. Genetic variation on mangrove forest, Kandelia candel (L.) Druce (Rhizophoraceae) in Southern China. The Symposium on the Phylogeny, Biogeography and Conservation of Fauna and Flora of East Asian Region, 177-188, (1997).

19. J.L. Hamrick, M.J.W. Godt, and S.L.Sherman-Broyles, Factors influencing levels of genetic diversity in woody plant species. New Forest 6:95-124, (1992).

20. P.D. Abeysinghe, L. Triest, B.De Greef, N. Koedam, and S. Hettiarachi, Genetic and geographic variation of the mangrove tree Bruguiera in Sri Langka. Aquatic Botany 67:131-141, (2000).

21. S. Jian, T. Tang, Y. Zhong, and S. Shi, Variation in inter-simple sequence repeat (ISSR) in mangrove and non-mangrove populations of Heritiera littoralis (Sterculiaceae) from China and Australia. Aquatic Botany 79: 75-86 (2004).

22. H.S. Li, and G. Z. Chen. Genetic diversity of Sonneratia alba in China detected by inter simple sequence repeats (ISSR) analysis. Acta Botanica Sinica 46(5):515-521. (2004)

23. T.L. Maguire, P. Saenger, P. Baverstock, and R. Henry. Microsatellite analysis of genetic structure in the mangrove species Avicennia marina (Forsk.) Vierh. (Avicenniaceae). Molecular Ecology 9:1853-1862 (2000). 
24. K.S. Bawa, Breeding systems of tree species of a lowland tropical community. Evolution 28:85-92 (1974).

25. M. Slatkin, Gene flow and the geographic structure of natural populations. Science 236:787-792 (1987).

26. D.R. Govindaraju, A note on the relationship between outcrossing rate and gene flow in plants. Heredity 61:401-404 (1988).

27. J. Nunez-Farfan, C.A. Dominguez, L.E. Eguiarte, A. Cornejo, M. Quijano, J. Vargas, and R. Dirzo, Genetic divergence among Mexican populations of red mangrove (Rhizophora mangle): geographic and historic effects. Evolutionary Ecology Research 4:1049-1064, (2002).

28. K.S. Bawa, D. R. Perry, and J. H. Beach. Reproductive biology of tropical lowland rain forest trees. I. Sexual systems and incompatibility mechanism. American Journal of Botany 72:331-345 (1985).

29. M. Basyuni, R. Wati, Bioinformatics analysis of the oxidosqualene cyclase gene and the amino acid sequence in mangrove plants, Journal of Physics : Conferece Series 801012011 (2017).

30. M. Basyuni, Sumardi, Bioinformatics approach of salt tolerance gene in mangrove plant Rhizophora stylosa, Journal of Physics: Conference Series 801012012 (2017). 